\title{
Client Orientation of Consumers as a Factor of Value- Based Development of Retail Chains Services
}

\author{
Valeeva Julia Sergeevna \\ Kazan State Power Engineering University \\ Kazan, Russia \\ valis2000@mail.ru
}

\author{
Jaromir Veber \\ Masaryk Institute of Advanced Studies Czech Technical \\ University in Prague \\ Prague, Czech Republic \\ jaromir.veber@cvut.cz
}

\author{
Galina Ostapenko \\ Masaryk Institute of Advanced Studies Czech Technical University in Prague \\ Prague, Czech Republic \\ Galina.Ostapenko@cvut.cz
}

\begin{abstract}
The article presents methodology of research of client orientation of consumers within the framework of ensuring consumer value of retail chains services. Four main evolutionary stages of development of the theory of client orientation of consumers, which began in the eighteenth century, are identified to the present. Based on the analysis of domestic and foreign concepts of client-oriented approach, three groups of orientation are identified, including orientation to the market, orientation to the client and proximity to the client. We have established that client orientation is an important tool for value development of trade service, as it allows to develop a unique offer for consumers, to build appropriate business processes of trade service and to develop organizational culture of trade organization. The main levels of development of client orientation are allocated: individual level - at the employee level, organizational level - client orientation of the organization, interfirm level - client orientation of the value creation chain. A feature of the method of evaluation of customer orientation of consumers is application of value approach, which consists in assessment of personnel involvement in creation of consumer value of retail chains service and efficiency of trade service provision. The approbation of the value approach was carried out in three retail chains, which made it possible to allocate areas of improvement of the trading service aimed at ensuring client orientation.
\end{abstract}

Keywords: client orientation of consumers, value-based development, retail chains

\section{INTRODUCTION}

A new tendency in creating value for trade services is a client-oriented strategy. The system of service, creation of amenities and personalized relations are the basis of clientoriented approach for management of trade organizations. Client orientation as a factor of consumer value development is emphasized in the works of Boldak R. "a large company should strive to be client-oriented, virtual and aimed at meeting the intentions of the consumer (future needs), that is, actively create potential demand, manage it and lead the consumer. This requires the introduction of customer-centric business models "where surplus-free products and distribution channels integrate and closely interact with key consumer values"; Implement business models that satisfy consumer intentions "[1].

The hypothesis of the study is that client orientation of consumers is the main element of formation of consumer value of retail trading chain service.

The point of the client-oriented approach in modern aspect is to sell as many goods as possible and fully provide consumer value of the trading service to one buyer, as opposed to previous approaches, when one brand needs to sell to as many buyers as possible.

The main objectives of the study are to consider existing approaches to the study of the content of the orientation of the activities of organizations in order to ensure economic development, to highlight levels of client orientation and to determine the relationship between client orientation of consumers and the lost value of retail chain services, to propose a system of indicators of socio-economic aspects of client orientation, to carry out testing and to develop appropriate recommendations to the objects of the study.

\section{Methods}

The essence of the client-oriented approach in today 's aspect is to sell as many goods as possible and fully provide consumer value of the trading service to one buyer, as opposed to previous approaches, when one brand needs to sell to as 
into account that value is formed through the relationship of satisfaction and costs of consumers, at this stage minimization of costs of the consumer was the main client-oriented request. Stage 3 - the end of the XX century - with the arrival of foreign retailers and manufacturers, the accelerated transition of russian trading organizations to a client-oriented approach, the use of merchandising technologies, the organization of effective distribution of trading space, internal advertising, placement of goods. Client orientation through direct contact with the consumer. The main value of the service of the trading network is to improve the quality of service, developing communications with consumers.

Customer value of service - It is the ratio between the benefits that the consumer receives from the purchase and use of a service and the costs of acquiring and using [28]

The fourth stage - 21 cent. - client orientation in the network format at the inter-firm level, including at the personnel level. The service is pre-sales and sales as a system, processing of personal data of clients, transition to a personalized client approach. All these requests predeterminate the development of a value-based approach in the provision of trade services. Formation of total consumer value, starting from the agricultural producer and to the final consumer.

A description of the client orientation methodology first began to appear in writings in the second half of the 20th century. The category "client orientation" was initially considered at the micro level and positioned in terms of "market orientation" by scientists such as P. Drucker, A. Kohli, T. Levitt, J. Narver, S. Slater, B. Jaworski. In his writings, Drucker determined that only in marketing, value was based on consumer satisfaction of necessary goods with appropriate consumer properties.

Kohli and Jaworski market orientation concept [7]. (MARKOR) began in the early 1990s, where the client was the source of profit of the organization, so market information flows about consumer value should come not only from the marketing department, but from any other division of the organization. Not enough to get information about customer's needs, it is important to meet their needs better than competitors. Their empirical research has shown that clientoriented employees will not perform negative actions in terms of the strategy of the enterprise, but will be oriented towards making deals, on satisfaction of consumer value, which will allow to profit the organization. Note that customer orientation was considered from different positions.
The first period of 18-19 centuries provided for interaction between consumers and sellers in the role of craftsmen, grocers. Demand and supply were balanced as artisans manufactured and sold the goods on their own. The reference point was on the customer and full satisfaction of consumer value, as they worked under the order of the customer's needs. The second period - the beginning-middle of 20 century. The main aspect of client orientation was the provision of more affordable prices through the application of new modern technologies of organization of mass production. The relevance to personalized sales for that period declined. The director-marketing was used, which is a model of a clientoriented approach. The main instrument was price. Taking 
TABLE I. SYNTHESIS OF CLIENT-ORIENTED APPROACH IN THREE ORIENTATION GROUPS [8]

\begin{tabular}{|c|c|c|}
\hline Orientation & Scientists & Content \\
\hline $\begin{array}{l}\text { Customer- } \\
\text { oriented sales }\end{array}$ & Weitz, Saxe & $\begin{array}{l}\text { Consumer orientation } \\
\text { through sales assistance }\end{array}$ \\
\hline $\begin{array}{l}\text { Orientation to } \\
\text { the market }\end{array}$ & 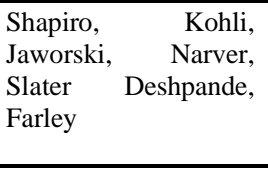 & $\begin{array}{l}\text { Organizational culture is a } \\
\text { company built on constant } \\
\text { collection of market } \\
\text { information on current and } \\
\text { future needs of clients }\end{array}$ \\
\hline $\begin{array}{l}\text { Orientation to } \\
\text { the customer }\end{array}$ & $\begin{array}{lr}\text { Narver, } & \text { Slater, } \\
\text { Lamben, } & \text { Hennig- } \\
\text { Thurau } & \text { T., } \\
\text { Deshpande et al. } & \end{array}$ & $\begin{array}{l}\text { Customer is a top priority } \\
\text { over other stakeholders as it } \\
\text { ensures long-term } \\
\text { profitability of the company }\end{array}$ \\
\hline $\begin{array}{l}\text { Proximity to the } \\
\text { customer }\end{array}$ & Peters, Waterman & $\begin{array}{l}\text { Active interaction with } \\
\text { clients to ensure the } \\
\text { necessary service and } \\
\text { quality, as well as to adapt } \\
\text { products to the needs and } \\
\text { requirements of consumers. }\end{array}$ \\
\hline
\end{tabular}

According to the selected approaches of customer orientation of consumers made by Rozhkov A.G., a group of scientists of the Nizhny Novgorod State University, it is possible to define general characteristics for companies that are oriented to the market and the client. The customer is the main source for developing the components of consumer value of the trading service. Strategic and tactical solutions of the company, on the basis of its needs new products and services are developed, necessary services and additional services are provided. In general, it is necessary to state that the organizational culture of the company is formed, which directs the efforts of all structural divisions to the value requests of consumers.

As part of the value approach, client orientation maximizes consumer value by reducing transaction costs through collaboration and customer interaction. It is client orientation that creates unique advantages through the development of proposals for consumers of more interesting values than competitors. A high level of value will be expressed in unique products or services, and most importantly within the framework of interaction of customer-oriented business processes, management decisions and organizational culture of the trading organization.

Modern consumer market trends expand opportunities for consumers with additional service components within the framework of retail chain service, therefore it is legitimate for F.Kotler to believe that the orientation should not only be on the needs of clients, but also on additional characteristics... "successful companies increase the value of their customer base, ahead of others in reducing the share of low-profit clients, increasing the duration of interaction with each client, turning low-profit clients into profitable - Or give them up and focus on high-value clients "[9].
TABLE II. CUSTOMER ORIENTATION LEVELS

\begin{tabular}{|c|c|c|c|}
\hline Levels & Objects & \multicolumn{2}{|c|}{$\begin{array}{c}\text { Authors who investigated client } \\
\text { orientation }\end{array}$} \\
\hline $\begin{array}{l}\text { Individual } \\
\text { level }\end{array}$ & $\begin{array}{l}\text { customer } \\
\text { focus of the } \\
\text { employee }\end{array}$ & $\begin{array}{l}\text { R. Saxe, B.A. } \\
\text { Weitz }\end{array}$ & $\begin{array}{l}\text { Apenko, } \\
\text { Kostanyan, } \\
\text { Popov, }\end{array}$ \\
\hline $\begin{array}{l}\text { Organizational } \\
\text { level }\end{array}$ & $\begin{array}{l}\text { Client- } \\
\text { oriented } \\
\text { organization, } \\
\text { department or } \\
\text { unit }\end{array}$ & $\begin{array}{lr}\text { A.K. } & \text { Kohli, } \\
\text { F.E., } & \text { Jr. } \\
\text { Webster, } & \text { J.U. } \\
\text { Farley, } & \text { B.P. } \\
\text { Shapiro, } & \text { B.J. } \\
\text { Jaworski, } \\
\begin{array}{l}\text { Narver, } \\
\text { Slater, }\end{array}\end{array}$ & $\begin{array}{l}\text { Rebyazina, A.G. } \\
\text { Rozhkov, } \\
\text { Smirnova M.M., } \\
\text { Tretiak O.A., } \\
\text { Shavrovskaya } \\
\text { M.N., } \\
\text { Sheresheva M.Y. } \\
\text {, Shirsheva O.I. , }\end{array}$ \\
\hline $\begin{array}{l}\text { Level of } \\
\text { intercompany } \\
\text { interaction }\end{array}$ & $\begin{array}{l}\text { Client } \\
\text { orientation of } \\
\text { counterparty } \\
\text { in value } \\
\text { creation chain }\end{array}$ & $\begin{array}{l}\text { K.G. Grunert, } \\
\text { C. Moorman, } \\
\text { A. Rindfleis, } \\
\text { U. Elg, Narver, } \\
\text { S. Slater, }\end{array}$ & $\begin{array}{l}\text { Chkalova O.V., } \\
\text { Efremova M.V., } \\
\text { Yuldashev O.U. }\end{array}$ \\
\hline
\end{tabular}

Client orientation as a factor of consumer value in this study is considered from three positions: consumer and personnel, inter-firm interaction, which ensure the level of development of retail chain services, providing the aggregate value of the chain of creation of consumer value. Gradation by three levels can be seen in a number of works of Klepneva O.V. [10]., Rozhkov A.G, Rebyaziya V.A., Smirnova M.M. [11]. and others presented in Table II.

In the context of this study, within the framework of the value-oriented approach, client orientation of consumers means a set of tools that ensure the creation of aggregate consumer value for the client through positive consumer experience and long-term relations formed under the influence of an effective system of quality management of the organization of the retail chain service.

Consumer value and its structure. The structure of consumer value is a set of certain elements, each of which can be considered as a separate value to the consumer, but collectively these elements tend to create a higher aggregate consumer value due to the synergistic effect.

In the following studies, Narver J., Slater S. [12] pay attention to regular buyers, meeting their needs through their full involvement in the value chain of the product, taking into account the needs not only of customers, but also of all members of the distribution channel movement or the chain of consumer value [13]. The authors define a marketing concept as a specific organizational culture consisting of a set of norms and values, in which the client heads the activities of the organization. This important component is valuable in terms of retail chain, so the counterparties of service interaction, including the consumer, together create aggregate consumer value. The research of Narver, Slater presents the relationship between market orientation and innovation activity of organizations, believing that by investigating the needs of the market, the organization is mobile to respond to requests and embeds innovative solutions in its activities.

The advantage of the concept of scientists Ramani, Kumar [15] in relation to the trade sector is important to indicate that they emphasize consumer involvement. Consider quantifying 
almost half of the customers, but most of all in the STM consumer is attracted by the low price. important component of personnel - content of interaction with the consumer - is not taken into account for the trading service.

Let us highlight the Oiner O.K. [16] conceptual model of the company's market orientation, based on the assessment of the impact on results in business using the client-oriented concept [17]. This modern model is useful for the retail sector of the economy in that there is a correlation between expenditure and performance, i.e. consumer value will allow to plan profit for the economic entity of the economy. This approach is also used in the works of Chkalova O.V. as... "the ability of the organization to generate additional profits through deep understanding and effective satisfaction of customers" needs, as well as client orientation is a tool for forming loyal buyers. The level of client orientation also reflects the choice of entrepreneurs between short-term and long-term goals " [18].

\section{DISCUSSION}

Thus, in the most general sense, client orientation... "it is a characteristic of the business. It reflects the position of the client's interests in the system of priorities of management and owners "[19]. As Rozhkov A.G. notes "client orientation is a strategy of the enterprise aimed at taking into account and meeting the needs of the client and forming maximumcomfortable relations with him. The goal: to ensure long-term professional interaction "[19], which allows to build on a longterm basis relation between retail chains and clients, to develop appropriate loyalty programs, to form inter-firm communications within the network itself.

At the same time, we will agree with the position of Losev S.V. that... "client orientation is the company's efforts to study the needs of consumers, create value for them and develop skills to anticipate new consumer problems," but for retail chains an important component is the orientation and to the personnel, who forms the quality of trading services, implements the standards of the quality management system [20].

Loyalty of clients is assessed through their satisfaction with the consumer value of the service through special loyalty programs, which allow to use the services of the trading chain according to the most favourable conditions, additionally motivating regular buyers to cooperate and to form joint consumer value. And the second component is consumer costs. If the client focuses not only on the price and its costs, the important component is emotional loyalty of buyers through satisfaction with the brand image, social activity, corporate social responsibility. Loyal customers who allow to increase the average check, to ensure positive reputation, are an effective element of word of mouth, potential consumers of new services and goods [21].

The share of modern retail in Russia has already reached $61 \%$. It is expected to rise to $79 \%$ by 2021 and bring Russia closer to European indicators. The number of buyers of their own chain brands is growing rapidly. Now the share of CTM is only $5 \%$ of the FMCG market, but penetration (number of buyers) reaches $96 \%$. The quality of products is satisfied with

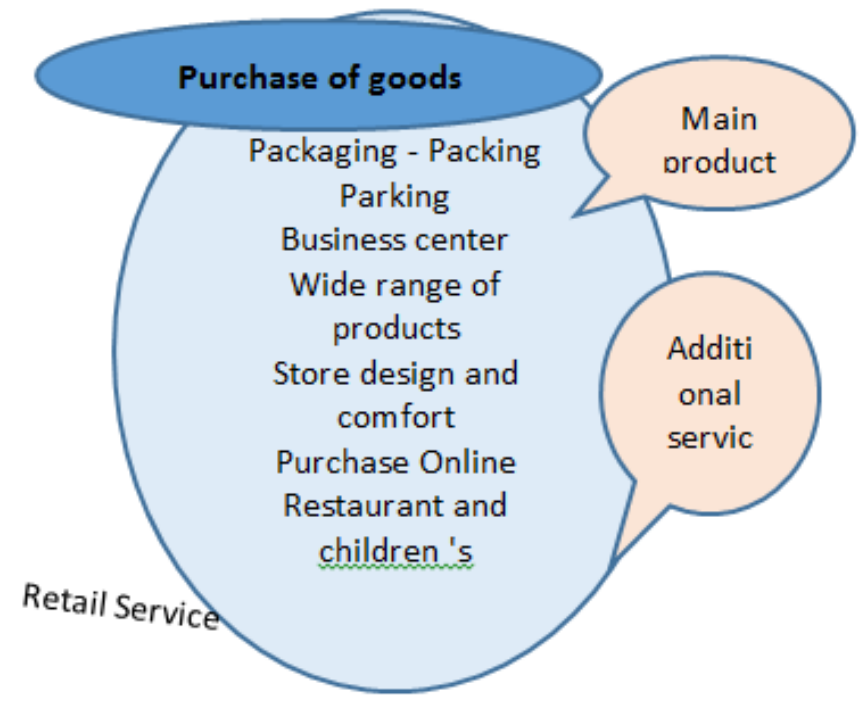

Fig. 2. Service concept (consumer value): main product and additional services

There is an increase in the share of professional "discount hunters" - cherry pickers buyers, whose basket by more than $50 \%$ consists of goods under discount offers. Over five years, the share of promo lovers has increased from $3 \%$ to $16 \%$, and the number of non-saving consumers has halved [22]. These statistics indicate a systematic work with loyal buyers. CTM allows you to attract new customers by minimizing costs and quality consumer characteristics of products and services.

Hygiene-characterized additional services are elements of services that consumers take for granted. If they are absent or provided at a low level, consumers will be disappointed.

TABLE III. SERVICE AS VALUE: HygIENE AND ENHANCEMENT FACTORS

\begin{tabular}{|l|l|}
\hline \multicolumn{1}{|c|}{ Hygiene factors (mandatory elements) } & \multicolumn{1}{|c|}{$\begin{array}{c}\text { Increasing factors } \\
\text { (optional) }\end{array}$} \\
\hline $\begin{array}{l}\text { Safekeeping of baggage } \\
\text { Clean toilet } \\
\text { Courtesy Crew }\end{array}$ & $\begin{array}{l}\text { Comfortable seats } \\
\text { Fast Baggage Delivery } \\
\text { Clean Salon }\end{array}$ \\
$\begin{array}{l}\text { Comfortable temperature and air humidity place for feet } \\
\text { Clear information about all changes in } \\
\text { flight time }\end{array}$ & $\begin{array}{l}\text { Good food } \\
\text { Efficient Pre-Order Service } \\
\text { Assistance with transfers to } \\
\text { other flights }\end{array}$ \\
$\begin{array}{l}\text { Availability of baggage carts } \\
\text { Possibility to get a pillow and blanket in } \\
\text { flight and etc. }\end{array}$ & \\
\hline
\end{tabular}

Additional services characterized by increasing factors it is optional services, their absence does not lead to dissatisfaction. The increasing factors are divided into elements of equality and excellence - depending on whether the firm wants to meet the average service level or offer something unique 
U. Elg [25] presented the inter-firm client orientation using transactional marketing tools, based on the results of the partnership study he conducted an analysis of the organization's process orientation to the market as part of the creation of value for the client. Note that Kohli and Jaworski, Narver, Slater conducted empirical research using broad sampling and quantitative measurements, mainly according to industrial enterprises that develop and produce a certain physical product, use intermediaries and other participants to bring the product to market. Retail trade is based on a combination of services, equipment acquisition and product sales, is more complex in structure [26], as it provides coordination of an extensive network of stores and partners to present a unique offer [27]. As in other service areas, retail is direct customer contact, daily interactions and orientations. In addition, retailer's mobile response to market requests and behaviour. Given that retail chains operate in local, regional and national markets, including corporate or inter-firm, the organization must therefore be customer-oriented to the market at several levels.

Thus, having considered the existing methodological approaches to the study of client orientation of consumers, it has been established that in modern conditions the role of ventilation trading chains should pay the greatest attention to establishing communication with consumers, have received natural connections, ensure maximum achievement of consumer value through the lens of social and economic aspects.

Testing of this approach was carried out on three retail chains Bahetle, Essen, Edelweiss, geographically located in the Republic of Tatarstan of Russia and its other regions. As a result, the following data were obtained, which are presented in the table IV.

TABLE IV. RESULTS OF CUSTOMER ORIENTATION CALCULATIONS

\begin{tabular}{|c|c|c|c|c|c|c|c|c|c|}
\hline \multirow[t]{2}{*}{ Indicator } & \multicolumn{3}{|c|}{ «Bahetle» } & \multicolumn{3}{|c|}{ «Edelweiss» } & \multicolumn{3}{|c|}{ «Essen » } \\
\hline & $\stackrel{n}{\frac{n}{2}}$ & $\stackrel{b}{\grave{2}}$ & $\widehat{\approx}$ & $\stackrel{2}{2}$ & 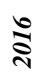 & $\stackrel{\curvearrowright}{\approx}$ & $\stackrel{\text { in }}{\approx}$ & $\stackrel{b}{\stackrel{\sim}{*}}$ & $\stackrel{\curvearrowright}{\approx}$ \\
\hline $\begin{array}{l}\text { Economi } \\
\text { c value of } \\
\%\end{array}$ & 81 & 86 & 92 & 85,5 & 93,5 & 94,7 & 90,2 & 94,6 & 95,5 \\
\hline $\begin{array}{l}\text { Social } \\
\text { value, in } \\
\text { shares }\end{array}$ & 2,43 & 2,86 & 2,94 & 1,49 & 1,97 & 2,1 & 2,3 & 2,94 & 2,98 \\
\hline
\end{tabular}

An important indicator for the buyer is the value of the potential buyer's life cycle, which describes the expected level of value of services through additional costs its value is the average in trading networks at 3,7. The evaluation of consumer value consists of obtaining additional emotional benefits, which in "Bahetle" decreased by 2,5 points in 3 years, in "Essen" increased by 1,3 points. This shows the level of provision of additional emotional benefits within the framework of programs "Support of young mothers" in "Essen," flexible system of discounts and availability of club card. As for the commitment rate - a sufficient level was 
It has been established that existing approaches to the observed in the "Bahetle" trading chain, and the smallest level of the "Edelweiss" chain. This is primarily due to the quality of service and "Bahetle" service, which allows to meet the minimum requirements of any entering the trading chain.

Offers for TC "Bahetle" to enhance customer LTV (Life time value) by:

\section{1) changes of TA (target audience):}

- Increasing the frequency of site visits or visits of store;

- increases in number of orders;

- Increase the number of categories in orders;

- Range extensions within the category;

- prevention of outflow.

2) Increase in profitability from TA:

- increases in the average check;

- Higher share of high-yield purchases;

3) decrease in operational expenses:

- Lower number of abandoned baskets and returns;

- Reduced number of repurchase cancellations on delivery;

- Inventory optimization through better understanding of customer needs.

The idea of dividing functions between development and support departments, or decentralizing the IT department when each department is delegated its IT specialist, seems reasonable to eliminate the gap between IT and business. There is so many strategies, the main thing is to understand that the project of implementation of data analysis in the company can be successful only when it is not assigned to the IT department, but is supervised and managed by strategic business divisions. Advanced API features for integration with the customer's enterprise systems. This solution is intended for collection and analysis of data on transferred checks and reconciliation of data displayed in internal corporate systems with data transmitted by OFD(operator of fiscal data) to FTS(federal Tax Service). The system provides for prompt receipt of data and generation of reports in the required format.

\section{CONCLUSION}

In today 's world, with the development of retail chains, the traditional value chain is undergoing fundamental changes. On the one hand, "clean" distributors as a wholesale link are gradually displaced by retailers and manufacturers, who seek to establish direct connections, and "clean" distributors remain only a function of material logistics for the movement, storage and logistics processing of goods. On the other hand, more importantly, retail changes the direction of the chain and effectively becomes a generator of demand for new products for manufacturers, drawing the necessary quantity, including through its own brands as opposed to the ejector model in the chain with an active distributor role. management of trade services are based on economic or social efficiency.

The retailer's current key goals include increasing demand, attracting customers, and analyzing their behaviour and preferences. Three underlying strategies need to be followed to achieve these goals: client orientation; optimal infrastructure; and effective use of relationships with business partners and suppliers.

New technologies continuously modify the ways customers interact with retailers. Today's customers pay particular attention to the value of the products and services offered, so retailers must form a personalized, interactive interaction, encouraging interest and emphasizing respect for each consumer's preferences, whatever channels and forms of interaction they choose.

Innovation in mobile application platforms makes customer interaction easier. Retailers can provide customers with smartphone apps to create and use virtual shopping lists; Search for information about store services; Use of geographic information and navigation services, etc.

Using big data in retail, retail chain stores become more customer-oriented and can provide with necessary quality of services thanks to personalisation of offers and improvement of marketing strategy.

\section{REFERENCES}

[1] R. Baldock, "The Last days of the Giants?", 2000.

[2] M. V. Efremova and O. V. Chkalova, "Generalization and systematization of approaches to the definition of the term "customer focus"", Bulletin of the Nizhny Novgorod University, N.I. Lobachevsky, Series: Social Sciences, N. Novgorod: Publishing House of Nizhny Novgorod State University N.I. Lobachevsky, 2016, no. 2 (42), pp.1725.

[3] V. V. Busarkina, "The concept of customer orientation of the enterprise and the problems of its evaluation", Problems of the modern economy, 2007, no. 4 (24), pp. 179-182.

[4] A. Zinkevich, "Secrets of customer focus", M .: Mann, Ivanov and Farber, 2013, $43 \mathrm{p}$.

[5] O. A. Tretyak and A. G. Rozhkov, "Customer orientation: modeling and diagnostics", Bulletin of the Russian Economic University G.V. Plekhanova, 2012, no. 4 (46), pp. 76-84.

[6] O. V. Chkalova and V. V. Lunev, "The genesis of the customer-oriented pp. 143-147.

[7] A. Kokhli and B. Yavorsky, "Market Orientation: Construction, research proposals and managerial implications", Journal of Marketing, 1990, no. 54, pp. 1-18.

[8] V. G. Frolov, M. V. Lyubimova, T. V. Savitskaya, I. Yu. Khramova, Yu. V. Chemodanova, and T. K. Chikulisheva, "Methods for assessing the effectiveness of managing an organization in implementing a customeroriented approach", Russian Journal of Entrepreneurship, 2014, vol. 15, no. 16 , pp. $16-26$

[9] A. G. Rozhkov, "Formation and development of customer-oriented company relations the dissertation for the degree of candidate of economic sciences", Nat. researched University of Higher School of Economics, Moscow, 2012.

[10] P. Kotler, "Marketing Management", Express course, St. Petersburg: Peter, 2006, 446 p., 58 p. approach in Russia and abroad", Bulletin of SamGUPS, 2014, no. 2 (24), 
[19] Client orientation of the company [Electronic resource]. Available at: http://www.crmonline.ru/phparticles/show_news_one.php?n_id=402 (Accessed: 13 February 2019).

[11] A. G. Rozhkov, "Customer focus management in an international company", the dissertation ... candidate of economic sciences, 08.00.05, Moscow, 2016, 189 p., pp. 7-8.

[12] O. V. Chkalova and Yu. S. Valeeva, "Change in the economic paradigm of trade in the conditions of innovative activity of trading networks", Scientific Review: Theory and Practice, 2018, no. 9, 64 p.

[13] J. C. Narver and S. F. Slater, "The Effect of a Market Orientation on Business Profitability", Journal of Marketing, 199054 (4), pp. 20-35.

[14] J. C. Narver, S. F. Slater and D. L. MacLachlan, "Responsive and Proactive Market Orientation and New-Product Success", Journal of Product Innovation Management, 2004, 21, pp. 334-347.

[15] N. Kumar, L. Sheer, and P. Kotler, "From market driven to market driven", European Management Journal, 2002, vol. 18, no. 2.

[16] O. G. Oiner and L. S. Latyshova, "Personnel customer orientation is a key factor in the company customer orientation", In the collection: Modern management: problems and prospects, Collection of articles: in two parts, 2016, pp. 343-346.

[17] O. G. Oiner and L. S. Latyshova, "The influence of market-oriented behavior of companies on business performance. International scientific conference on the problems of economic and social development", Text in 3 books, M.: Publishing House of the Higher School of Economics, Book 2, 2009, pp. 287-296.

[18] O. V. Chkalova and E. A. Yukhneva, "The relationship of culture, customer focus and competitiveness of trade organizations", In the book: Actual problems of economics and management, Collection of scientific articles, Electronic edition, 2016, pp. 314-317.

[20] A. G. Rozhkov, "Formation and development of a customer-oriented company", dis .. cand. econ. Sciences, 2012, p. 22 [Electronic resource] Available at: http://www.hse.ru/data/2012/05/31/ 1225457000/disser_Rozhkov.pdf (Accessed: 8 November 2015).

[21] S. V. Losev, "Equal to the client: the basic principles of building a customer-oriented organization", Marketing in Russia and abroad, 2007, no. 6 , pp. $31-41,35$ p.

[22] B. H. Schmitt, "Experience Marketing: Concepts, Frameworks and Consumer Insights", Foundations and Trends in marketing, 2010, no. 2, vol. 5 [Electronic resource]. Available at: https://www.shopolog.ru/metodichka/attracting-clients/kak-nayti-balansmezhdu-uderzhaniem-klientov-i-privlecheniem-novyh/

[23] U. Elg, "Market orientation processes in retailing: a cross-national study", European Journal of Marketing, 2007, vol. 41, no. 5/6.

[24] P. McGoldrick, "Retail Marketing", 2nd ed., McGraw-Hill, London, 2002.

[25] J. Dawson, "Viewpoint: retailer power, manufacturer power, competition and some questions of economic analysis", International Journal of Retail and Distribution Management, 2000, vol. 28, no. 1, pp. $5-8$.

[26] S. F. Slater, "Developing a customer value-based theory of the firm", Journal of the Academy of Marketing Science, 1997, pp. 162-167. 